\title{
Analysis of Land Use Land Cover Change Detection of Bostanlik District, Uzbekistan
}

\author{
Mukhiddin Juliev*, Alim Pulatov², Sven Fuchs' ${ }^{1}$, Johannes Hübl ${ }^{1}$ \\ ${ }^{1}$ Institute of Mountain Risk Engineering, University of Natural Resources and Life Sciences, Austria \\ ${ }^{2}$ EcoGIS Center, Tashkent Institute of Irrigation and Agricultural Mechanization Engineers, Tashkent, Uzbekistan
}

Received: 16 January 2018

Accepted: 11 August 2018

\begin{abstract}
This paper presents the change detection analysis of two multispectral datasets for the Bostanlik District of Tashkent, Uzbekistan, using Landsat-5 TM data for 1989 and Landsat-8 OLI for 2017. Both supervised classification and maximum likelihood algorithms were utilized for the change detection analysis. Six land use classes were identified: snow cover, bare soil/rock, forest, waterbody, built-up areas and agriculture. The change detection technique showed that within 28 years, significant changes occurred in the classes of the forest, built-up areas, bare soil and snow cover. The presented results might be valuable for the government authorities and stakeholders for future land use planning activities.
\end{abstract}

Keywords: Landsat, Bostanlik, change detection, remote sensing, Uzbekistan

\section{Introduction}

Land use and land cover (LULC) are two different terms generally assessed in combination since the first (physical properties of surface elements) and the latter (human use of land cover) cannot be seen as independent from each other $[1,2]$. Consequently, LULC represents the result of human-environment interaction within a given area [3-8], influenced by the dynamics given by climate change processes and socio-economic dynamics [9-11]. Nowadays the most prominent methods are remote sensing techniques for LULC change detection. Multi-temporal remote sensing (RS) based on change detection analysis has repeatedly been used in different aspects of land cover change [12, 13].

*e-mail: mukhiddinjuliev@gmail.com
RS platforms continuously capture the Earth's surface and decision makers can easily apply satellite imagery to monitor dynamics of change. LULC change analysis using RS techniques gives an opportunity to obtain results with low costs, less time consumption and good accuracy, and geographical information systems (GIS) allow updating results whenever new data is available [14, 15]. Utilization of open source data is a good choice to improve the skills in RS and GIS tools, in particular for scientists from less-developed countries. In this context, Landsat satellite images are frequently used for LULC change detection analysis. With RS data, different change detection algorithms are available and repeatedly applied, such as principal component analysis, fuzzy classification, and post classification methods $[16,17]$.

Different supervised classification methods are applied for LULC change detection. In this research, we built on research published on LULC change for 
Uzbekistan and countries in Central Asia. Yin et al. [18] produced a forest cover map for Central Asia using multi-resolution satellite imagery from Landsat and MODIS for the years 2009-2011. Kraemer et al. [19] analyzed the agricultural land cover change in Kostanay Province for 1953 to 2010. Based on multi-temporal Landsat TM/ETM+ datasets, they applied Support Vector Machine techniques to map the agricultural land cover change. Furthermore, Edlinger et al. [20] used Landsat MSS and TM data for the years 1972, 1977, 1987 and 2000 to compute the expansion of irrigated croplands in the Kashkadarya Province, Uzbekistan, based on decision trees; and their results showed good accuracy for the cropland change.

From the given references we can observe that most publications have so far centered on western and southwestern Uzbekistan. In order to expand information on LULC, we chose a study area in northeastern Uzbekistan; the area is a less-populated region and includes large areas falling under different land protection laws.

The area is characterized by Ugam Chatkal National Park located in the Bostanlik, Akhangaran and Parkent districts. The park was founded in 1992 and it is the largest natural protection area in Uzbekistan with a total area of $5,746 \mathrm{~km}^{2}$ and a border to Kazakhstan in the north and Kyrgyzstan in the east. The main objective of the national park is biodiversity conservation, and as such the fauna counts more than 280 species, among them 44 species of mammals, 200 birds, 16 species of reptiles, 2 amphibians and 20 varieties of fish [21]. The park is home to approximately 2,200 different species of plants. One of the main tasks for responsible ecologists is to preserve and extend the forested area of the park. A large part of the national park is open to tourists, which creates management challenges. In 2016, Ugam Chatkal National park was added to the UNESCO World Heritage sites list [22].

Bostanlik District is one of the landslide-prone areas of Uzbekistan and most of the landslides are triggered by snow melting and precipitation. The presence of a mountain reservoir increases the frequency of landslide occurrence, in particular for areas near the waterbody. Around $65 \%$ of total landslides in Uzbekistan are located in Tashkent Province [23]. Since Bostanlik is not only a very important place for nature conservation but also for the socio-economy of Uzbekistan, the monitoring of existing landslides is necessary, and a landslide susceptibility zonation is highly recommended in order to mitigate these hazards. LULC is a main parameter for landslide susceptibility analysis. Consequently, the main objective of the current study was the application of open source datasets for LULC change detection analysis using RS and GIS techniques for the given area. Our research was the first attempt for LULC change detection for Tashkent Province, and the applied methodology provided the expected results.

\section{Materials and Methods}

Study Area

Bostanlik is located in the northeastern part of Uzbekistan, between $41^{\circ} 00^{\prime}$ and $42^{\circ} 20^{\prime}$ north and

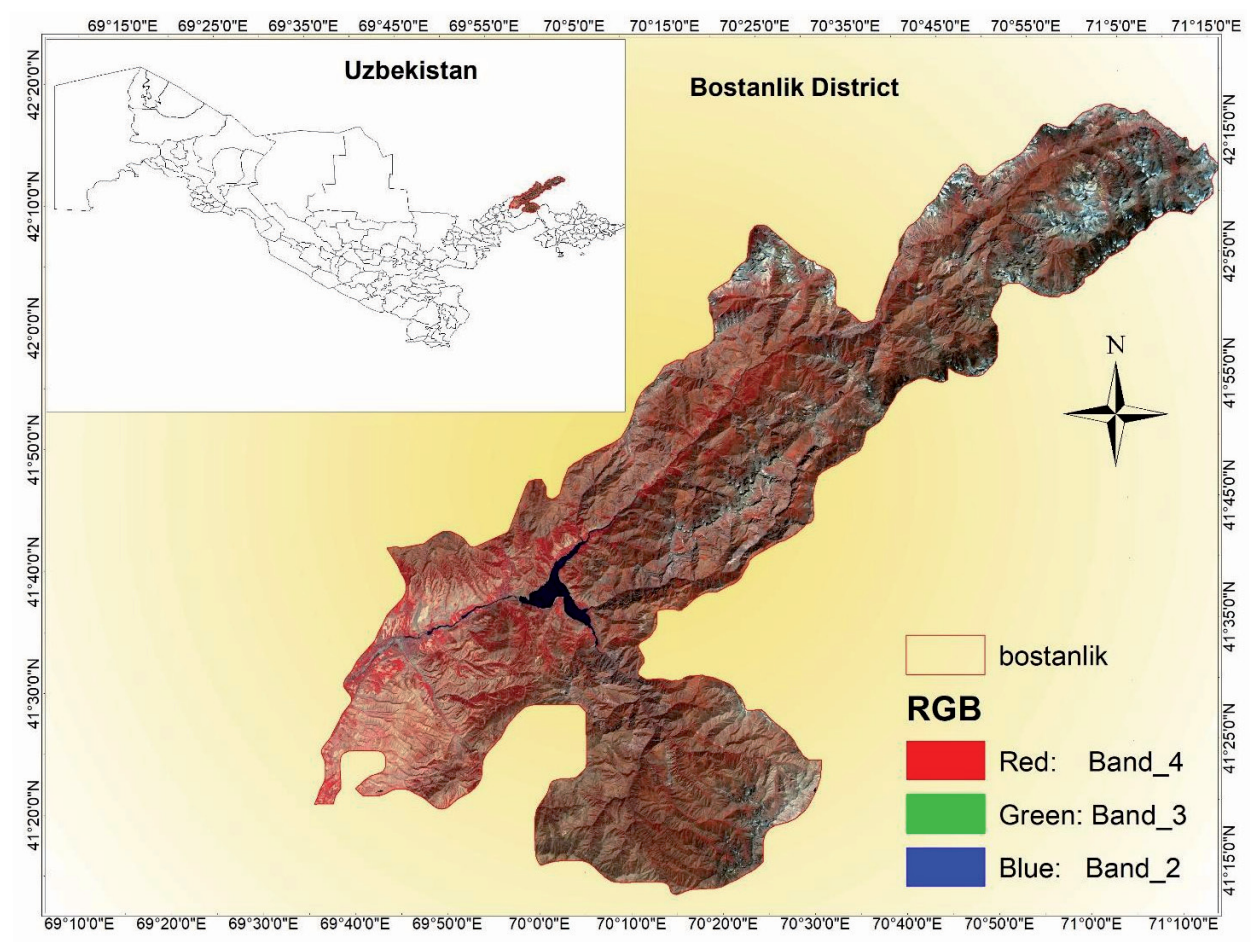

Fig. 1. Location of the study area. 
$69^{\circ} 30^{\prime}$ and $71^{\circ} 20^{\prime}$ east. The distict covers 4,982 $\mathrm{km}^{2}$ and it is the largest district in the Tashkent region (Fig. 1). Almost the entire part of the study area is covered by high mountains such as the Western Tien Shan, Karzhantau, Pskem, Ugam and Chatkal, and the altitude range of the district varies from 568 to $4,301 \mathrm{~m}$ a.s.l. The altitude of the district increases from west to east and from south to north. Bostanlik belongs to the western part of the Tien Shan Mountain range. The highest point of the district is Adelung peak at $4,301 \mathrm{~m}$ a.s.1. The district belongs to the seismically active zone and more than eight earthquakes occur on an annual average. The climate of the territory belongs to the continental type; annual mean minimum, maximum and absolute minimum and maximum temperatures of the area are $-9^{\circ} \mathrm{C},+21^{\circ} \mathrm{C},-26^{\circ} \mathrm{C}$ and $+46^{\circ} \mathrm{C}$, respectively. On average the district receives about 800-1200 mm precipitation per year. The main river of the area is the Chirchik. Within the district, the mountain reservoir operates with an area of coverage $40 \mathrm{~km}^{2}$ and with 2 billion $\mathrm{m}^{3}$ of storage volume. The administrative center of the district is the city of Gazalkent. According to the census of 2000 , there were 142,900 people living in the district and according to the census of 2013, about 160,000 people inhabit the area with more than $60 \%$ of the residents living in rural areas. The largest recreation sites of Uzbekistan are located in Bostanlik.

\section{Data Preparation and Processing}

For the current study, Landsat 5 TM (thematic mapper) data of 28 May 1989 and Landsat 8 OLI (operational land imager) data of 27 May 2017 provided by the USGS (United States Geological Survey) Earth
Explorer database system were used for generating LULC maps. The spatial resolution of both imageries is the same and equals $30 \mathrm{~m}$. The topography of the study area is mountainous and ground reference data was obtained by visual interpretation of the images and using Google Earth Pro, and the current reference data used for the classification of the study area. All the processing and post-classification steps were completed using the software packages ENVI 5.1 and ArcGIS 10.1. The preprocessing steps included the assignment of the coordinate system, layer stacking of the separate bands of the datasets and subsetting the images based on the polygon of the study area. Supervised classification methods and maximum likelihood algorithm were used for preparing LULC maps. Maximum likelihood algorithms are well-known and were repeatedly used effectively in assessing satellite imageries [24]. Finally, six types of LULC classes were identified in the study area: snow cover, bare soil/rock, forest, waterbodies, built-up areas and areas used for agriculture. For obtaining more accurate LULC maps, for each land use class 15 training samples were selected. Fig. 2 and 3 show the final output of LULC maps for 1989 and 2017, respectively. Accuracy assessment was performed to verify the quality of the obtained results for the classified maps. In total 15 polygons from each class were selected to assess the accuracy of the obtained results. The overall accuracy for the data from 1989 was $90.91 \%$, and $80.49 \%$ for 2017 . Kappa coefficient for 1989 was 0.8830 and for 2017 was 0.7492 . Finally, for showing the change detection results a post-classification method was applied, and the LULC change direction and change detection matrix between initial and final states was evaluated.

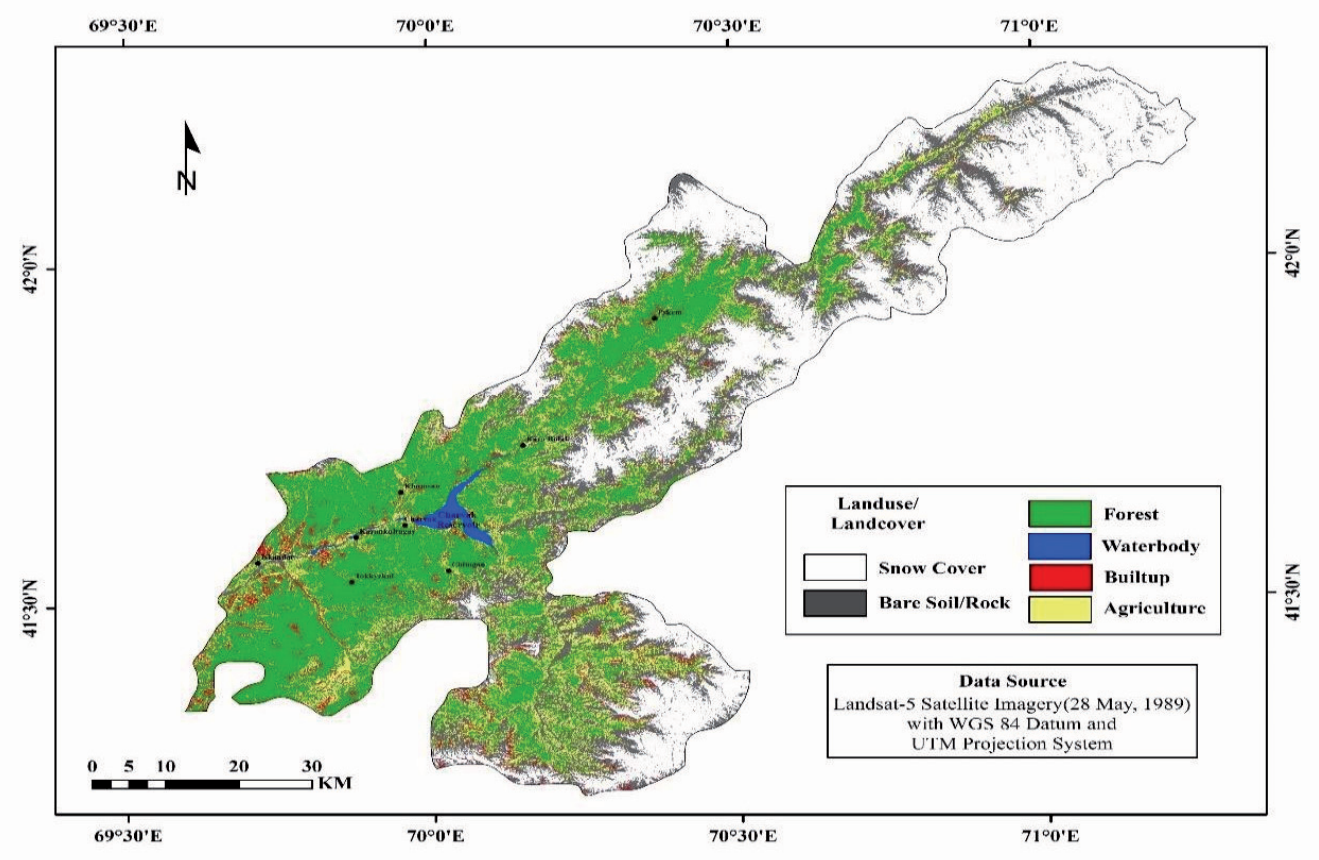

Fig. 2. Land use and land cover map (28 May1989). 


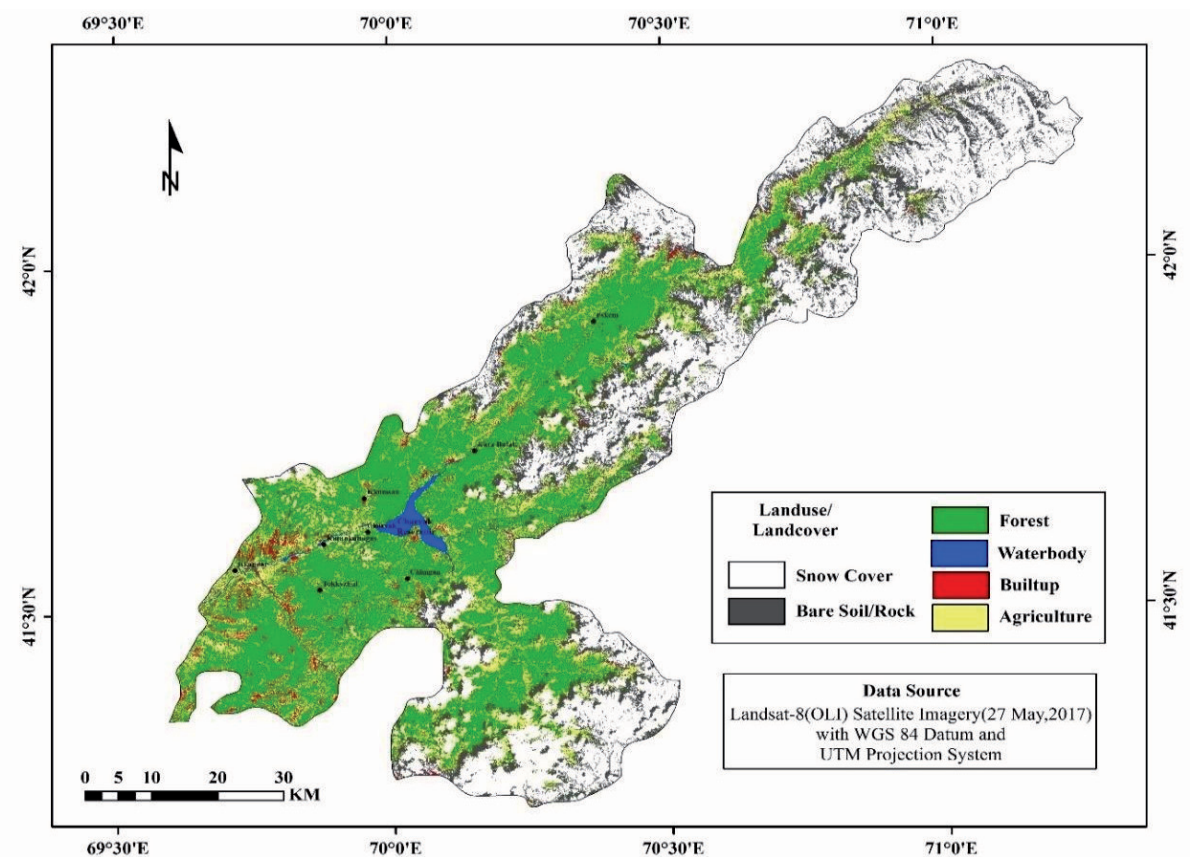

Fig. 3. land use and land cover map (27 May2017).

\section{Results and Discussion}

\section{LULC Change Direction}

All classes were named generally and they may further be divided into subclasses, such as snow cover, which also included glaciated areas, bare soil and rock, which represented exposed soil and bedrock; forest, which included meadows and mixed forested areas; waterbodies, which included both rivers and reservoir; built-up areas, which included residential, commercial and industrial subclasses; and finally the class of agriculture that can be further divided into crop fields and fallow fields. In Fig. 2 and 3 the spatial distribution of LULC for the given years is provided. The classified image for 1989 is divided into six classes, with 30.5\% $\left(1519.6 \mathrm{~km}^{2}\right)$ of the area covered with forest, $30.3 \%$ $\left(1511.3 \mathrm{~km}^{2}\right)$ with snow, $0.7 \%\left(36.2 \mathrm{~km}^{2}\right)$ with water, $13.1 \%\left(655 \mathrm{~km}^{2}\right)$ with agriculture, $24.5 \%\left(1118.6 \mathrm{~km}^{2}\right)$ with bare soil and $1.7 \%\left(86.4 \mathrm{~km}^{2}\right)$ with built-up areas. About $36.2 \%\left(1804.1 \mathrm{~km}^{2}\right)$ of the area of the 2017 image is classified as forest, $30.2 \%\left(1504.9 \mathrm{~km}^{2}\right)$ as snow, $0.8 \%$ $\left(38.9 \mathrm{~km}^{2}\right)$ as water, $13.2 \%\left(656.9 \mathrm{~km}^{2}\right)$ as agriculture, $17.3 \%\left(863.3 \mathrm{~km}^{2}\right)$ as bare soil and $2.3 \%\left(113.9 \mathrm{~km}^{2}\right)$ as built-up areas.

The results achieved after processing the two multispectral datasets of Landsat $5 \mathrm{TM}$ and 8 OLI for change detection are given in Fig. 4 and Tables 1 and 2. A decline occurred in the classes of bare soil and snow cover, but the classes of forest, built-up areas and agriculture were increased (Table 1). Snow cover class decreased from $1511.3 \mathrm{~km}^{2}$ to $1504.9 \mathrm{~km}^{2}$ and class bare soil declined from $1118.6 \mathrm{~km}^{2}$ to $863.3 \mathrm{~km}^{2}$. The forest class increased from $1519.6 \mathrm{~km}^{2}$ to $1804.1 \mathrm{~km}^{2}$, built-up areas increased from $86.4 \mathrm{~km}^{2}$ to $113.9 \mathrm{~km}^{2}$ and a slight increase was observed for both the waterbodies and areas used for agriculture.

Results have shown that over the 28-year period under investigation, perceptible LULC changes occurred in Bostanlik. Over this period, the forest area increased by $5.7 \%$, which proves the protective status of the area. Accordingly, a lot of ongoing projects on flora and fauna protection in the Western Tien Shan and Ugam Chatkal National Park can be observed. The data given in the Mongabay rainforests database shows that Uzbekistan had an increment in forested area between 2000 and 2005 , with an average of 16,700 ha per year. Annual reforestation amount was about $0.55 \%$. During this period, Uzbek forest cover increased by $8.2 \%$, or around 250,000 ha [25]. For the Ugam river watershed the Interstate Coordination Water Commission of Central Asia reported an increase in forest cover between 1998 and 2010 within the district [26].

The next class that got an increment is the builtup area, with a change of $0.56 \%\left(27.51 \mathrm{~km}^{2}\right)$ for the total area of the district. This is obvious since built-up areas expansion is related to the number of population and the population of the district increased from 142,900 to 160,000 in the period between 2000 and 2013. Population density in the Bostanlik district is 29.9 per $\mathrm{km}^{2}$, and from 2010 to 2013 the population increased by $5.4 \%$, with an annual rate of $1.8 \%$ [27]. The Bostanlik district is an area heavily influenced by tourism, with 40 villages, more than 10,000 households, 180 large recreation areas, resorts and children's camps, one mountain reservoir, four rivers, and $240 \mathrm{kms}$ of mountain roads - which is another reason for this increase. It should be noted that most of the recreation zones along Charvak Reservoir were built between 1989 and 2017. 


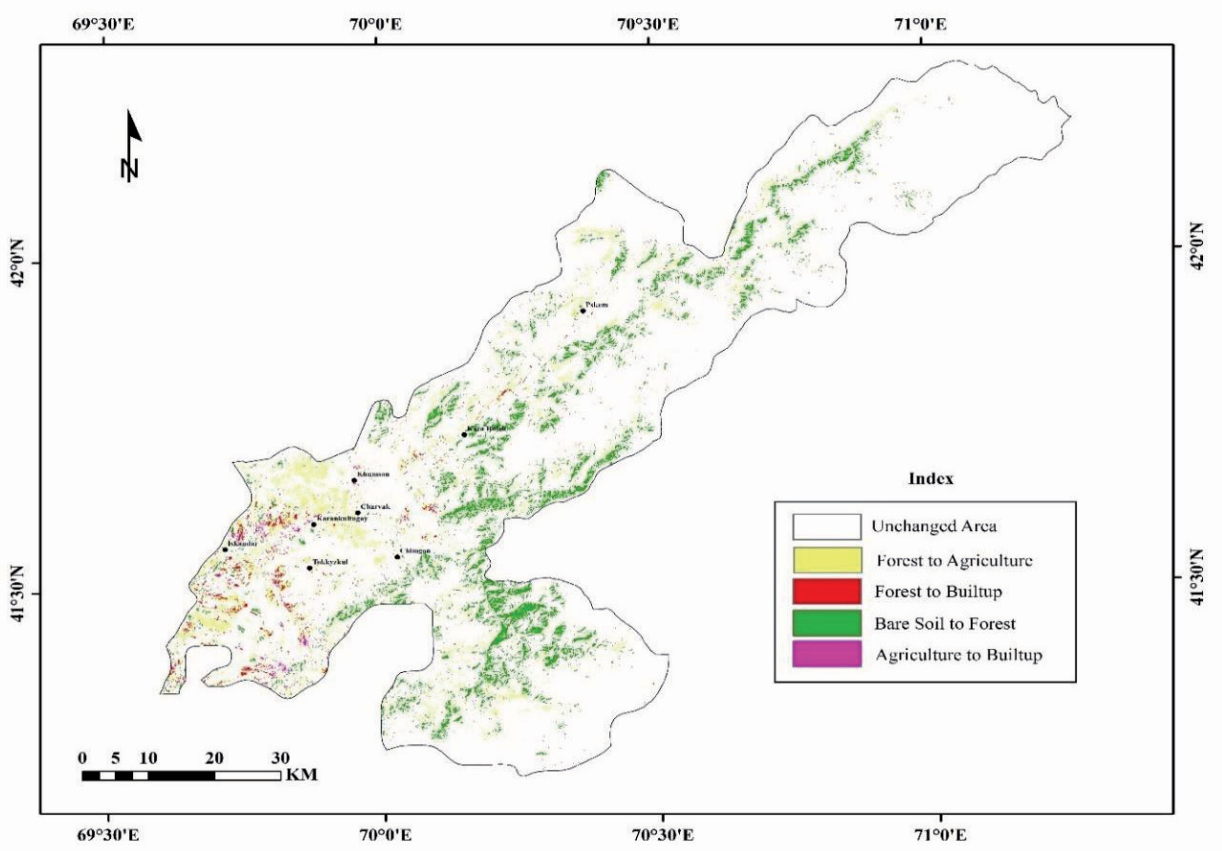

Fig. 4. Change detection map (1989-2017).

The waterbody class on the image mainly represents the Chirchik River and the Charvak Reservoir areas. By the classified images, a minor change in the waterbody class is detectable with only a $0.06 \%$ increase $\left(2.76 \mathrm{~km}^{2}\right)$. This result is mainly related to a seasonal issue of water abundancy during the month of May in Bostanlik. The Chirchik is formed by the joining of the rivers Pskem and Chatkal. According to the calculations conducted in the Chirchik-Ahangaran hydrological area, mountain river flow will not change during the next 20-30 years, though climate change can affect water discharge during the vegetation period. Glaciers of the Western Tien Shan are the main source for the water. In recent years we have observed that areas covered with glaciers and snow are decreasing, but most of research on glaciers have noted for the study region that this process does not affect much of the water flow to the rivers [28].

Table 1. Land use and land cover change direction (1989-2017).

\begin{tabular}{|c|c|c|c|c|}
\hline \multirow{2}{*}{ Landuse/Landcover } & \multicolumn{2}{|c|}{1989} & \multicolumn{2}{c|}{2017} \\
\cline { 2 - 5 } & $\begin{array}{c}\text { Area } \\
\left(\mathrm{km}^{2}\right)\end{array}$ & $\begin{array}{c}\text { Area } \\
(\%)\end{array}$ & $\begin{array}{c}\text { Area } \\
\left(\mathrm{km}^{2}\right)\end{array}$ & $\begin{array}{c}\text { Area } \\
(\%)\end{array}$ \\
\hline Forest & 1519.6 & 30.5 & 1804.1 & 36.2 \\
\hline Snow Cover & 1511.3 & 30.3 & 1504.9 & 30.2 \\
\hline Water body & 36.2 & 0.7 & 38.9 & 0.8 \\
\hline Agriculture & 655.0 & 13.1 & 656.9 & 13.2 \\
\hline Bare Soil & 1118.6 & 22.5 & 863.3 & 17.3 \\
\hline Built-up & 86.4 & 1.7 & 113.9 & 2.3 \\
\hline Total Area & 4982 & 100 & 4982 & 100 \\
\hline
\end{tabular}

Another class with increasing dynamics is the agriculture class, which rose by $1.86 \mathrm{~km}^{2}$. It is obvious that due to the observed increase in population the agricultural areas also increased, mainly because of subsidence farming: About $80 \%$ of the Bostanlik population inhabits small villages with its own agricultural fields.

Bare soil area is the class that declined the most, equal to minus $5.2 \%$ from the total area of Bostanlik. From Table 2 we can see that the bare soil class has changed to forest and agriculture classes. As the study area befalls the protected zone of Uzbekistan from 1992, the main effort is being paid for the afforestation of the area. Most probably this is the one of the main reasons behind the decline of the soil class. The other reason for this could be the sufficient amount of water availability during March to June, when the mountain area meadows and forests have very high normalized difference vegetation indices (NDVI), but due to extremely hot weather conditions and from heavy grazing of meadows this index decreases regularly starting in July.

The area covered with snow and glaciers indicated a decrease from 1989 to 2017. Degradation of glaciers over 28 years amounted to $6.33 \mathrm{~km}^{2}(0.127 \%)$ from the total area of the district, with an annual rate of degradation of $0.225 \mathrm{~km}^{2}$. Due to the effect of climate change and the temperature increase in mountain areas, most of the small glaciers disappeared. Regression of glaciers can develop the glacial lakes in mountain areas; from previous research on glacier extent using remote sensing satellite datasets in the Bostanlik district, it has been proven that the area covered with glaciers changed by minus $0.12 \%$ from 2007 to 2013 , confirming the results of our study [28]. 
Table 2. Change detection matrix between initial and final state (1989-2017).

\begin{tabular}{|c|c|c|c|c|c|c|c|c|}
\hline & \multicolumn{8}{|c|}{ Initial State (1989) } \\
\hline \multirow{9}{*}{$\begin{array}{l}\text { Final } \\
\text { State } \\
2017\end{array}$} & & Snow Cover & Water body & Forest & Bare Soil & Agriculture & Built-up & Class Total \\
\hline & Snow Cover & 1163.1 & 0.2 & 65.0 & 192.4 & 78.7 & 17.3 & 1504.9 \\
\hline & Water body & 0.4 & 35.1 & 0.2 & 3.0 & 0.2 & 0.0 & 38.9 \\
\hline & Forest & 5.6 & 0.1 & 1191.2 & 279.1 & 289.4 & 1.0 & 1804.1 \\
\hline & Agriculture & 10.5 & 0.1 & 190.3 & 208.8 & 212.7 & 34.5 & 656.9 \\
\hline & Built-up & 1.6 & 0.0 & 26.3 & 20.0 & 18.3 & 20.3 & 113.9 \\
\hline & Bare Soil & 330.1 & 0.7 & 46.7 & 415.3 & 55.8 & 14.7 & 863.3 \\
\hline & Class Total & 1511.3 & 36.2 & 1519.6 & 1118.6 & 655.0 & 86.4 & 4982.0 \\
\hline & Change Class & -6.3 & 2.8 & 284.5 & -255.3 & 1.9 & 27.5 & \\
\hline
\end{tabular}

\section{Change Detection Matrix between Initial and Final States}

Change detection matrix between the initial (1989) and final (2017) states was calculated using ENVI 5.1 software. Table 2 shows the shifts of land cover classes over a 28 year period. From $1511.26 \mathrm{~km}^{2}$ of snow cover, $1163.06 \mathrm{~km}^{2}$ remained as the same class in 2017, $0.4 \mathrm{~km}^{2}$ were converted to waterbodies, $5.6 \mathrm{~km}^{2}$ to forests, $10.5 \mathrm{~km}^{2}$ to agriculture areas, $1.6 \mathrm{~km}^{2}$ to built-up areas and $330.1 \mathrm{~km}^{2}$ to the class of bare soils during this period. There is no significant change for the waterbody class as only $0.7 \mathrm{~km}^{2}$ of the area was converted to the bare soil class in 2017. For the forest area from 1989 with the total area of $1519.6 \mathrm{~km}^{2}, 1191.2 \mathrm{~km}^{2}$ retained in this class in 2017 and $65.0 \mathrm{~km}^{2}$ were replaced by the snow cover class, $190.3 \mathrm{~km}^{2}$ by the agriculture class, $46.7 \mathrm{~km}^{2}$ by the bare soil class and $26.3 \mathrm{~km}^{2}$ by the built-up areas. $415.3 \mathrm{~km}^{2}$ from $1118.6 \mathrm{~km}^{2}$ of bare soil area remained as in this class in $2017,279.1 \mathrm{~km}^{2}$ were converted to the forested area, and $208.8 \mathrm{~km}^{2}$ were converted to agricultural areas. Out of $655.0 \mathrm{~km}^{2}$ of the agriculture class $212.7 \mathrm{~km}^{2}$ remained in this class in 2017 and the remaining part of the area mostly replaced by the forest, snow cover and bare soil classes. About $66.1 \mathrm{~km}^{2}$ out of $86.4 \mathrm{~km}^{2}$ for the built-up areas was converted to the agriculture, snow cover and bare soil classes during this period because during this period many recreational zones were built in this area. Accordingly, built-up class areas were converted to other classes and vice versa. The current change direction in built-up class has to be checked with the local experts and local statistical data.

The study had shown that change detection techniques using remote sensing and GIS can give valuable results about land cover changes over longer periods. Results may be further used for landslide susceptibility analysis, glacier monitoring and glacier lake outburst flood detection, forest biomass estimation and biodiversity conservation in the Bostanlik area.

\section{Conclusion}

Remote sensing methods with accurate input data and monitoring results can support assessing the further behavior of LULC processes. The achieved results show that within 28 years the LULC of the Bostanlik District changed significantly. We observed an increment for forests, built-up areas, waterbodies and agriculture classes, and we verified the obtained results with already existing results from fellows using other methods of assessment. There are different agencies involved for the sustainable development of Ugam Chatkal National Park and the entire Bostanlik Province, which are conducting the various activities.

The study area exhibits different geomorphological phenomena such as erosion, glacial lake outburst floods, debris flows, and landslides - all of which can turn into hazards once elements are at risk. The LULC maps resulting from this study will be further used for landslide susceptibility mapping of the district, which will support the governmental authorities and stakeholders to establish land-use planning for the Bostanlik District in order to prevent natural hazard losses. Moreover, the results obtained may help to achieve the sustainable development of the entire region by providing necessary input data.

\section{Acknowledgements}

Current research was carried out with the support of the TIMUR project funded by the Erasmus Mundus Action 2 program. The authors would like to thank colleagues from the Institute of Mountain Risk Engineering for their suggestions on a previous version of this manuscript.

\section{Conflict of Interest}

The authors declare no conflict of interest. 


\section{References}

1. RAWAT J.S., KUMAR M. Monitoring land use/cover change using remote sensing and GIS techniques: A case study of Hawalbagh block, district Almora, Uttarakhand, India. The Egyptian Journal of Remote Sensing and Space Science, 18 (1), 77, 2015.

2. TURNER M.G., RUSCHER C.L. Changes in landscape patterns in Georgia, USA. Landscape Ecology, 1 (4), 241, 1988 .

3. YANG A., SUN G. Landsat-Based Land Cover Change in the Beijing-Tianjin-Tangshan Urban Agglomeration in 1990, 2000 and 2010. ISPRS International Journal of GeoInformation, 6 (3), 59, 2017.

4. GONG P., WANG J., YU L., ZHAO Y., ZHAO Y., LIANG L., CHEN J. Finer resolution observation and monitoring of global land cover: first mapping results with Landsat TM and ETM+ data. International Journal of Remote Sensing, 34 (7), 2607, 2013.

5. FUCHS S., RÖTHLISBERGER V., THALER T., ZISCHG A., KEILER M. Natural Hazard Management from a Coevolutionary Perspective: Exposure and Policy Response in the European Alps. Annals of the American Association of Geographers, 107 (2), 382, 2017.

6. LÓPEZ E., BOCCO G., MENDOZA M., DUHAU E. Predicting land-cover and land-use change in the urban fringe. Landscape and Urban Planning, 55 (4), 271, 2001.

7. RUIZ-LUNA A., BERLANGA-ROBLES C.A. Land use, land cover changes and coastal lagoon surface reduction associated with urban growth in northwest Mexico. Landscape Ecology, 18 (2), 159, 2003.

8. CHEN Y., LI X., LIU X., AI B. Analyzing land-cover change and corresponding impacts on carbon budget in a fast developing sub-tropical region by integrating MODIS and Landsat TM/ETM+ images. Applied Geography, 45, 10, 2013.

9. VERBURG P.H., NEUMANN K., NOL L. Challenges in using land use and land cover data for global change studies: LAND USE AND LAND COVER DATA FOR GLOBAL CHANGE STUDIES. Global Change Biology, 17 (2), 974, 2011.

10. YUAN F., SAWAYA K.E., LOEFFELHOLZ B.C., BAUER M.E. Land cover classification and change analysis of the Twin Cities (Minnesota) Metropolitan Area by multitemporal Landsat remote sensing. Remote Sensing of Environment, 98 (2-3), 317, 2005.

11. WANG X., ZHENG D., SHEN Y. Land use change and its driving forces on the Tibetan Plateau during 1990-2000. CATENA, 72 (1), 56, 2008.

12. LI X., ZHAO S., YANG H., CONG D., ZHANG Z. A Bi-Band Binary Mask Based Land-Use Change Detection Using Landsat 8 OLI Imagery. Sustainability, 9 (3), 479, 2017.

13. ABD EL-KAWY O.R., RØD J.K., ISMAIL H.A., SULIMAN A.S. Land use and land cover change detection in the western Nile delta of Egypt using remote sensing data. Applied Geography, 31 (2), 483, 2011.

14. JOVANOVIC D., GOVEDARICA M., SABO F., BUGARINOVIC Z., NOVOVIC O., BEKER T., LAUTER $\mathrm{M}$. Land cover change detection by using remote sensing: A case study of Zlatibor (Serbia). Geographica Pannonica, 19 (4), 162, 2015.
15. LAMBIN E.F., GEIST H.J., LEPERS E. DYNAMICS OF LAND USE AND LAND COVER IN TOPICAL REGIONS. Annual Review of Environment and Resources, 28 (1), 205, 2003.

16. LU D., MAUSEL P., BRONDÍZIO E., MORAN E. Change detection techniques. International Journal of Remote Sensing, 25 (12), 2365, 2004.

17. PETIT C.C., LAMBIN E.F. Integration of multi-source remote sensing data for land cover change detection. International Journal of Geographical Information Science, 15 (8), 785, 2001.

18. YIN H., KHAMZINA A., PFLUGMACHER D., MARTIUS C. Forest cover mapping in post-Soviet Central Asia using multi-resolution remote sensing imagery. Scientific Reports, 7 (1), 2017.

19. KRAEMER R., PRISHCHEPOV A.V., MÜLLER D., KUEMMERLE T., RADELOFF V.C., DARA A., TEREKHOV A., FRÜHAUF M. Long-term agricultural land-cover change and potential for cropland expansion in the former Virgin Lands area of Kazakhstan. Environmental Research Letters, 10 (5), 054012, 2015.

20. EDLINGER J., CONRAD C., LAMERS J., KHASANKHANOVA G., KOELLNER T. Reconstructing the Spatio-Temporal Development of Irrigation Systems in Uzbekistan Using Landsat Time Series. Remote Sensing, 4 (12), 3972, 2012.

21. CHEMONICS INTERNATIONAL INC. Biodiversity Assessment for Uzbekistan (No. USAID CONTRACT NUMBER: LAG-I-803-99-00014-00) (p. 77). ALMATY, KAZAKHSTAN: USAID CENTRAL ASIAN REPUBLICS MISSION. Retrieved from https://rmportal. net/library/content/118_uzbekistan/view 2001.

22. MIR Corporation. New 2016 UNESCO Sites: Our 3 Picks for Sites in Uzbekistan and Iran. Retrieved from https:// www.mircorp.com/unesco-new-2016-uzbekistan-iran/ 2016.

23. JULIEV M., PULATOV A., HUBL J. Natural hazards in mountain regions of Uzbekistan: A review of mass movement processes in Tashkent province. International Journal of Scientific \& Engineering Research, 8 (2), 1102, 2017.

24. ABINO A.C., KIM S.Y., JANG M.N., LEE Y.J., CHUNG J.S. Assessing land use and land cover of the Marikina sub-watershed, Philippines. Forest Science and Technology, 11 (2), 65, 2015.

25. mongabay.com. Uzbekistan. Retrieved from https:// rainforests.mongabay.com/deforestation/archive/ Uzbekistan.htm 2006.

26. Interstate Coordination Water Commission of Central Asia. Report on the Watershed of Ugam River (p. 114). Retrieved from http://www.cawater-info.net/projects/pdf/ sic-ugam-report.pdf 2013.

27. BENSITOVA G.R., BESHKO N.YU., NURIJANOV D.A. Ecological-economical characteristics of Ugam-Chatkal National Park (p. 64). Tashkent. Retrieved from msri-hub. ucentralasia.org/file/6283/download/6570 2014.

28. SEMAKOVA E., GUNASEKARA K., SEMAKOV D. Identification of the glaciers and mountain naturally dammed lakes in the Pskem, the Kashkadarya and the Surhandarya River basins, Uzbekistan, using ALOS satellite data. Geomatics, Natural Hazards and Risk, 7 (3), 1081, 2016. 
